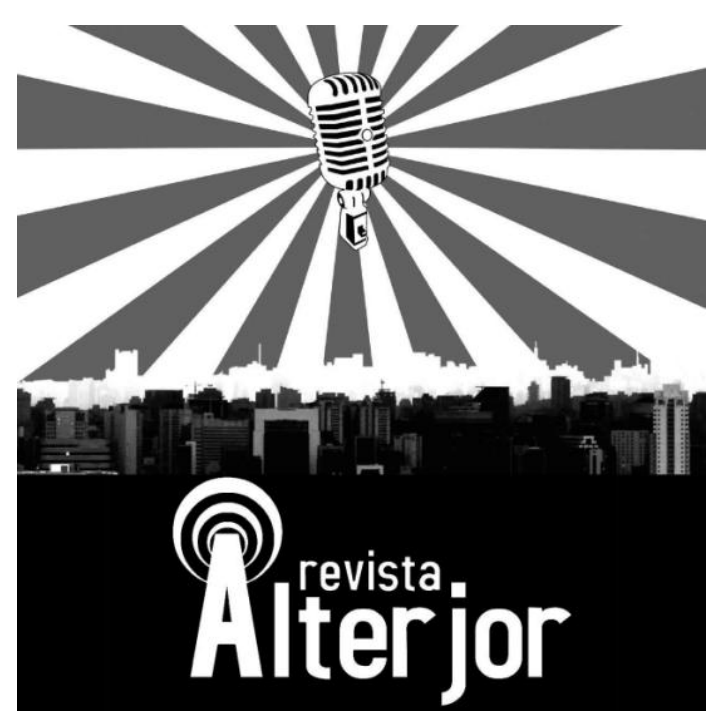

RELATÓRIOS DE PESQUISA

\title{
JORNALISMO IMPRESSO E AS FONTES: UMA ANÁLISE SOBRE O JORNAL DIÁRIO POPULAR
}

\author{
Lucas Casarin Kurz ${ }^{1}$ \\ Michele Negrini $^{2}$
}

RESUMO: Este estudo analisa as fontes presentes na página 3, de conteúdo especial, do jornal impresso Diário Popular de Pelotas, no Rio Grande do Sul. A partir de dez edições, todas do ano de 2019, realiza o mapeamento dos agentes presentes no texto, identificando seus papéis enquanto fonte de informação e traçando uma análise sobre qual o perfil do entrevistado pelo jornal neste espaço. A escolha do veículo se deu pela sua inserção na comunidade pelotense, possuindo grande relevância social e histórica na Zona Sul do Estado. A pesquisa tem como objetivo entender quais são as figuras presentes, sob hipóteses de questões como rotinização, padronização do uso de fontes e equilíbrio ou não da presença destes no texto.

PALAVRAS-CHAVE: Jornalismo impresso. Fontes. Diário popular. Análise de conteúdo.

ABSTRACT: This study analyzes the sources present on page 3, of special content, of the printed newspaper Diário Popular de Pelotas, in Rio Grande do Sul. From ten editions, all from the year 2019, it carries out the mapping of the agents present in the text, identifying their roles as a source of information and outlining an analysis of the interviewee's profile by the newspaper in this space. The vehicle was chosen due to its insertion in the Pelotan community, having great social and historical relevance in the South Zone of the State. The research aims to understand which figures are present, under the hypothesis of issues such as routine, standardization of the use of fonts and balance or not of their presence in the text.

KEYWORDS: Printed journalism. Sources. Popular daily. Content analysis.

\footnotetext{
${ }^{1}$ Jornalista pela Universidade Federal de Pelotas (2019); Pós-Graduando em Comunicação e Marketing (2020-2021). Tem atuação profissional em: RádioCOM Pelotas: 2016-17; Jornal Diário Popular - 2017-2019; Attra Comunicação 2019-presente; Beneficência Portuguesa de Pelotas - 2019-presente. E-mail: lucas.kurz@gmail.com

${ }^{2}$ Jornalista. Doutora em Comunicação pela PUCRS. Tem Pós-doutorado pela UFBA, no programa de Pós-Graduação em Comunicação e Cultura Contemporâneas. Professora da UFPEL. Email: mmnegrini@ yahoo.com.br
}

\section{Revista ALTERJOR}

Grupo de Estudos Alterjor: Jornalismo Popular e Alternativo (ECA-USP)

Ano 10 Volume ol Edição 23 Janeiro-Julho de 202l

Avenida Professor Lúcio Martins Rodrig̉ues, 443, Cidade Universitária, São Paulo, CEP: 05508-020 


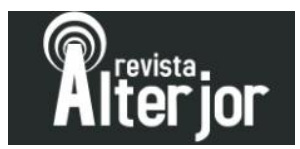

\section{Introdução}

As fontes são essenciais na formação do texto jornalístico. Em um mundo dinâmico e acelerado como o que vivemos, a informação surge a todo momento, de todo lugar, gerando interesse público, com os jornais sendo cada vez mais importantes enquanto organizadores deste fluxo de informação. Lage (2009) defende que são poucas as matérias que se originam da observação do repórter. Portanto, é preciso ter esse contato com quem testemunha, compreende, representa ou explica os fatos que ocorrem diariamente, de maneira a tornar tudo compreensível para qualquer leitor, uma das bases do jornalismo de qualidade, que deve ser claro para todos os públicos.

Essa perspectiva se aplica ainda mais ao jornalismo impresso de rodagem diária, que necessita de dinamismo e jogo de cintura para que, ao mesmo tempo que se procura a informação, tenha-se a agilidade de pensar em fontes e encontrar as figuras mais pertinentes para aquela história específica. Os repórteres normalmente acabam trabalhando em editorias específicas e os laços com as fontes acabam se estreitando. A rotina de fechar todos os dias uma ou mais páginas, com espaço mínimo necessário, com temas partindo do mesmo ponto, seja sobre a cidade onde está inserido, a política daquela região, ou fatos que englobam as diversas editorias que existem, gera essa proximidade com as fontes. E, por vezes, isso gera um acomodamento, no qual fica mais fácil procurar sempre as mesmas fontes, ou apoiando-se nos mesmos tipos.

Isso é vivido em diversos jornais, e no Diário Popular, localizado na cidade de Pelotas, Rio Grande do Sul, não é diferente. Tradicional fonte de informações na região, sendo um dos jornais mais antigos do país, possui grande credibilidade, trazida por sua idade e histórico de atuação com seriedade na prática jornalística.

Mas, ainda assim, o jornalista precisa ir atrás de fontes. De histórias novas para contar a cada dia. Da descoberta de novos fatos. Para conseguir realizar todos os protocolos e concluir sua jornada diária com um texto de qualidade e em curto espaço de tempo, é preciso descobrir a história, fazer contatos com as fontes, conversar com elas, apurar, checar, escrever, revisar, diagramar e rodar a impressão, para, nas horas seguintes, ser entregue ao leitor com qualidade e responsabilidade jornalística. 


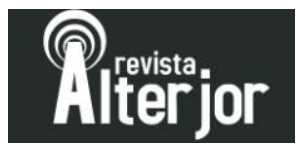

O presente trabalho busca entender a escolha por quais fontes o repórter busca utilizar no jornalismo impresso. Ao tentar mapear elas a partir das definições de Lage (2009) para fontes jornalísticas, realizando Análise de Conteúdo com base em Bardin (1977), o objetivo é entender como se dá essa divisão de personagens que são presentes no texto. Dessa maneira, queremos entender quem os repórteres do Diário Popular optam por utilizar como fonte e o que a presença destes indivíduos, assim como sua ausência, representa na hora de apresentar o texto final para o leitor. Ao evidenciar quais fontes possuem espaço neste jornal, pode-se verificar a pluralidade ou falta dela, bem como qual o papel destas fontes na construção de uma matéria jornalística.

Optou-se, então, por utilizar a página 3 da edição impressa do Diário Popular para esta análise. Por se tratar de uma página com conteúdos especiais, acaba fugindo de especificidades de uma editoria com viés único, afinal, é um espaço com ampla possibilidade de materiais. O recorte optou por analisar dez edições em um período de dez meses. Dessa maneira, as temáticas fogem de séries especiais em sequência, ou de épocas especiais, como datas comemorativas e eventos locais como feiras e festivais. A opção pela primeira edição de cada mês se deu pela percepção de que é uma data onde pode haver novidades sazonais, como foi o caso em algumas edições, ou trazer um tom de factualidade. O número de dez edições, entre janeiro e outubro de 2019 , se deu para ter uma quantidade ampla de materiais para análise, mas ao mesmo tempo mantendo-se em um espaço de tempo próximo ao momento da pesquisa.

Foram consideradas fontes pessoas, instituições ou documentos dos quais o texto especifica diretamente ter baseado-se para obter tal informação. Sabe-se que é hábito no jornalismo obter informações com fontes que acabam não citadas no texto, por vezes secretas, ou utilizadas só para obter um direcionamento na construção da pauta. Mas, como essas não ficam claras no texto, não é possível mapeá-las com o tipo de análise escolhida. 


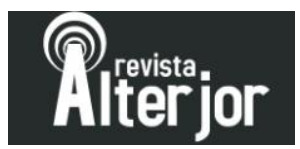

\section{Jornalismo impresso e as fontes}

As fontes possuem papel imprescindível para a formação do texto jornalístico. Lage (2009) ressalta que poucos conteúdos originam-se integralmente da observação direta, com a maioria das informações sendo fornecidas por instituições ou personagens que testemunharam ou participaram de eventos de interesse público. Há a ideia, adquirida talvez junto à literatura ou ao cinema, de que a fonte é uma figura obscura que fornece informações secretas ao repórter sobre temas guardado a sete chaves envolvendo órgãos governamentais ou pessoas poderosas. Mas a fonte raramente é anônima e pode ofertar diversos tipos de informações.

Em qualquer matéria jornalística, há o uso de fontes. Seja através da observação do próprio repórter ou da informação prestada por testemunhas, há sempre alguém ou alguma situação sendo citada. No jornal impresso, as fontes aparecem através de citações diretas ou indiretas, notas, materiais de assessorias, entre diversas outras possibilidades. Elas podem estar posicionando-se quanto a algum acontecimento ou opinando sobre um tema. Para Erbolato (2004) qualquer pessoa que presta uma informação ao repórter é tipificada como fonte, e tudo que é publicado no jornal parte de fontes, sendo definidas como fixas, ou seja, as que são consultadas frequentemente, ou como fora de rotina, sendo verificadas em casos excepcionais.

Fonte é qualquer pessoa que presta informações ao repórter. A tendência generalizou-se no sentido de se usar tanto fonte (no singular) quanto fontes (no plural). Porém, há notícias, como as relacionadas com os interesses da comunidade (fornecimento de água, de luz e o funcionamento dos telefones), que não precisam ser transmitidas misteriosamente por uma fonte, porque nada têm que deva ser ocultado. (Erbolato, 2004, p. 183)

São diversas as definições encontradas nos dicionários para a palavra fonte. No dicionário de Rios (2005), sua ótica jornalística é uma dentre onze definições, sendo considerada a "pessoa que fornece informações a um jornalista". Para Schmitz (2011) é necessário destacar a importância de diferenciar fonte de informação e fonte de notícia, pois enquanto a primeira se refere a qualquer informação disponível, a segunda precisa de um mediador. Herbert Gans (1980, apud Schmitz, 2011) define que fontes de 


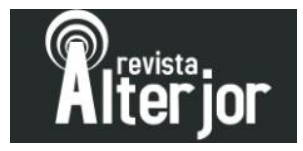

notícias são as pessoas que os jornalistas mantêm contato através de entrevista ou observação, provendo informações.

A relação entre jornalista e fonte, portanto, torna-se essencial para a construção do texto jornalístico. Lage (2009) diz que o resultado de uma consulta à fonte depende da intenção que ela atribui ao repórter, ou seja, qual a sua expectativa quanto ao resultado final daquela entrevista. Dessa maneira, não há outra saída para o jornalista se não criar essa relação de uma maneira que a fonte confie nele o máximo possível de informações e com a maior clareza possível no relato.

Essa relação pode ser descrita também como um exercício de troca, onde há interesse por parte da fonte para contribuir. Há fontes que queiram utilizar-se do espaço do jornalista para suprir outros interesses, mas cabe a este, junto de seus editores definir o que é notícia. Cotta (2005, p. 76) diz que notícia é a informação sobre algo ou alguém, sendo algo novo, inédito ou inusitado, que provoque impacto, interesse ou desperte a curiosidade das pessoas.

Em uma breve história do contato jornalístico com fontes, Lage (2009) relembra que até meados do século XX elas desempenhavam esse papel naturalmente, com funcionários públicos e pessoas de interesse sendo ouvidos por repórteres posicionados estrategicamente em pontos como portos, aeroportos e estações rodoviárias. O surgimento da assessoria de imprensa após Segunda Guerra Mundial mudou essa relação, com departamentos treinados para realizar essa mediação profissionalmente.

O surgimento das assessorias contribuiu decisivamente para a profissionalização do setor de informação pública, com delimitação clara de posições, tanto do lado de quem fornece a informação quanto de quem a coleta. Ficou mais nítida a posição do repórter como agente do público, sujeito, embora, ao contexto das relações econômicas e de poder de que nada escapa na sociedade - certamente não as empresas jornalísticas (LAGE, 2009, p. 51)

As fontes não são, necessariamente, pessoas públicas. Um observador que presenciou um crime pode prestar o relato ao repórter, ou um documento pode ser a comprovação fidedigna de um acontecimento que não é confirmado por pessoas. Mais recentemente, dados tornaram-se também fontes utilizadas em reportagens, lançando 


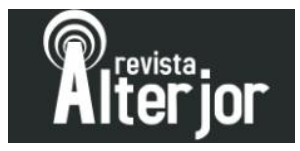

mão de informações obtidas através de números. Há também os especialistas, que podem ser consultados a partir de seu conhecimento profundo sobre o tema que está sendo abordado, ou também quem já vivenciou aquele caso anteriormente. Enfim, são diversos, e quase inumeráveis, os motivos para uma fonte ser solicitada a contribuir com um jornalista.

\section{Tipos de fontes}

São muitos os tipos de fontes, com autores dando as mais variadas definições. Erbolato (2004, p. 183) defende que elas são classificadas em dois grandes grupos, sendo consideradas fixas ou fora de rotina. Uma taxonomia proposta por Schmitz (2011, p. 22) diz que "As tipificações são frágeis diante da variedade de fontes e das formas de interferência nos procedimentos jornalísticos”. Ele expõe que diversos jornais possuem em seus manuais de redação variadas tipificações de fontes.

Este estudo, no entanto, se aterá a seguir a designação proposta por Lage (2009), englobando sua natureza em mais ou menos confiáveis, pessoais, institucionais ou documentais. A partir disso, ele as classifica em três tipos, sendo o primeiro as oficiais,

oficiosas e independentes, seguido de primárias e secundárias e finalizando em testemunhas e experts.

A definição de Lage (2009) diz que as oficiais são mantidas por instituições, desde o próprio Estado e órgãos ligados a ele, até empresas e instituições privadas, enquanto oficiosas são também ligadas a estas instituições, mas sem autorização, podendo ser refutadas. Por sua vez, as independentes são ligadas a organizações nãogovernamentais (ONGs), muitas vezes sob suspeição por possíveis extremismos, por possuírem interesse naquele tema. Alguns exemplos de fontes oficiais são institutos, pastas governamentais como secretarias e ministérios e os próprios políticos. Já as oficiosas são as fontes ligadas a essas instituições mas que falam off the record, ou seja, sem serem identificadas. Quanto às independentes, podemos citar as próprias ONGs.

Na sequência, Lage (2009) define como primárias as fontes consultadas durante a execução da matéria fornecendo as informações necessárias para a execução desta, 
citando como exemplo, em uma matéria sobre plantações, os plantadores e os agrônomos. As secundárias "são consultadas para a preparação de uma pauta ou a construção das premissas genéricas ou contextos ambientais." (Lage, 2009, p. 66), que neste caso citado, são consultadas, segundo Lage (2009), para apuração, podendo ser funcionários de instituições ligadas ao setor agrário ou até mesmo economistas.

Esse cuidado nos permite fazer perguntas mais adequadas e aprofundar o questionamento de respostas não convincentes. Em itens controversos ou que apresentam vários ângulos de abordagem, será bom partir de uma conversa com mais de uma fonte secundária, representando diferentes enfoques da matéria (Lage, 2009, p. 66)

Por fim, as definições de Lage (2009) apontam um terceiro setor de fontes, as testemunhas e experts. Ele ressalta que a testemunha é frequentemente afetada pela perspectiva, ou seja, ponto de vista que possuía quando presenciou o fato, mas com seu relato imediato sendo o de maior probabilidade de possuir mais autenticidade. É nesse grupo que é mais aconselhado pelo autor a utilizar-se da regra das três fontes. "Um bom princípio é só confiar em histórias contadas por três fontes que não se conhecem nem trocaram informações entre si”, Lage (2009, p. 67). Um exemplo de testemunho é a pessoa que dá o seu relato de uma situação que vivenciou, por exemplo quem viu um acidente de trânsito. Lage (2009) cita que o testemunho pode ser parcial, exemplificando que pode-se testemunhar uma guerra sem ter assistido a sequer uma batalha inteira. Por fim, os experts citados por Lage (2009) são fontes que dão versões ou interpretam eventos a partir de sua expertise naquela temática, mas que, apesar de terem tendência a didatizar a questão, podem acabar costurando o discurso a partir de suas próprias convicções. Exemplificam-se nesta categoria os considerados especialistas, como professores e médicos.

\section{O Jornal Diário Popular}

O Jornal Diário Popular foi fundado em 27 de agosto de 1890, enquanto órgão republicano, segundo Gonçalves (2019). Sua segunda fase relata Gonçalves (2019), iniciou-se em 1937, com responsabilidade comercial e contando como órgão de 


\section{Pition}

interesse geral. Com formato tabloide ${ }^{5}$, mantém circulação contínua há 129 anos. Circula nas cidades da Zona Sul do Rio Grande do Sul e é dirigido por Virgínia Fetter, tendo em Jarbas Tomaschewski seu editor-chefe. São cerca de 200 funcionários atualmente.

O Jornal possui diversas editorias, com uma matéria especial diária na página 3, e editorias fixas de Cidades, na qual é feita a cobertura de diversos fatos do município de Pelotas e região, com temas como saúde, educação e infraestrutura; Editoria de Cultura, que aborda temáticas culturais da região, como arte, cinema, teatro, música, gastronomia, entre outros; Editoria de Segurança, que traz as notícias com essa temática, como cobertura policial de crimes, sistema prisional e outras questões; Editoria de Economia, com a cobertura comercial da região; Editoria de Política, cobrindo as novidades quanto a administração dos municípios, partindo dos poderes Executivo, Legislativo, secretariado, entre outros; Editoria de Esportes, abordando principalmente o futebol, mas também outros esportes como futsal, handebol, vôlei, natação, entre outros; Editoria de Agronegócio, presente nas edições de domingo e quinta-feira, com temáticas sobre o agronegócio da região, como indústrias, plantações, perspectivas de safras, entre outros, além de espaços de opinião e um setor de webjornalismo, responsável pelo site e redes sociais do jornal.

\section{Perpectivas metodológicas}

Esta pesquisa utilizará como base analítica a proposta metodológica de análise de conteúdo apresentada por Laurence Bardin (1977). Os dados serão obtidos através da análise da página 3 da edição impressa do Diário Popular, selecionadas a partir da escolha da primeira edição do mês, nos dez primeiros meses do ano de 2019, ano no qual essa pesquisa está sendo realizada. No cabeçalho da página, ela é identificada como a editoria de Especial.

A análise se valerá das propostas de Lage (2009), tipificando os tipos de fontes, associadas à metodologia de Bardin (1977) para mapear as fontes utilizadas e como elas 


\section{Antion}

são apresentadas, e, a partir desse tabelamento, verificar quais são os tipos de fontes mais utilizados no Diário Popular.

A partir das definições, Bardin (1977) subdivide em três as categorias para realizar uma análise de conteúdo, enquanto sua organização. As fases são denominadas de pré-análise, exploração do material e tratamento dos resultados, inferência e interpretação.

Na pré-análise é quando ocorre a organização, de acordo com Bardin (1977). Nela, se projeta os objetivos e estabelece-se a maneira como se irá proceder. Bardin (1977) divide-a em três missões. "A escolha dos documentos a serem submetidos à análise, a formulação das hipóteses e dos objetivos e a elaboração de indicadores que fundamentam a interpretação final” (BARDIN, 1977, p. 95).

Na exploração do material, Bardin (1977) defende que seja feita aplicação das ideias elaboradas na pré-análise, desenvolvendo a sistemática prevista no primeiro momento, definindo-a como a mais cansativa das etapas. Por fim, a etapa do tratamento dos resultados obtidos e interpretação, Bardin (1977) diz que eles devem ser significativos e válidos. "O analista, tendo à sua disposição resultados significativos e fiéis, pode então propor inferências e adiantar interpretações a propósito dos objetos previstos" (BARDIN, 1977, p. 101).

\section{A análise das fontes usadas pelo Diário Popular}

A seleção do material para análise se deu a partir da definição pela página 3 do Diário Popular, um espaço definido como Especial já em seu cabeçalho, sem anúncios e com assuntos variados, podendo utilizar-se temáticas de qualquer editoria. Nela aparecem quase que sempre temas factuais, conforme pode-se verificar a seguir, ou séries especiais, tendo uma, sobre o dia da mulher, sido englobada no recorte da presente análise. É um espaço que não pertence a alguma editoria fixa, então temas como política, dia a dia, segurança, esportes ou economia, podem vir a aparecer a qualquer momento.

\section{Revista ALTERJOR}

Grupo de Estudos Alterjor:Jornalismo Popular e Alternativo (ECA-USP)

Ano 10 Volume Ol Edição 23 Janeiro-Junho de 2021

Avenida Professor Lúcio Martins Rodrig̉ues, 443, Cidade Universitária, São Paulo, CEP: 05508-020 


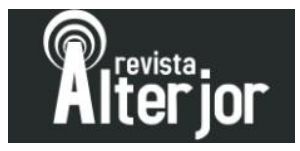

Para realizar a análise, serão mapeadas as fontes que aparecem em cada matéria dessas páginas, de acordo com a definição dada por Lage (2009). A análise de conteúdo será feita considerando o aporte teórico citado no item anterior.

\section{Período de matrículas escolares se inicia - Segunda-feira, 31 de dezembro de 2018 e terça-feira, $1^{\circ}$ de janeiro de 2019}

Neste dia, a edição foi em conjunto com o dia anterior, 31 de dezembro de 2018. É um padrão observado no Diário Popular que edições de sábado e domingo sejam conjuntas, assim como a de feriados e suas vésperas. Esse padrão será observado em outros itens mais adiante.

Esta edição contou com alguns destaques na capa como a retrospectiva do ano anterior, expectativas para o Réveillon na praia do Laranjal e a notícia de que um pelotense é recordista de diplomas. O texto da página 3, que será objeto de análise, foi destaque enquanto manchete do jornal, com a chamada "Mês de janeiro marca o período de rematrículas na rede pública de ensino”, seguida de uma linha de apoio com quatro linhas.

A matéria da página $3^{7}$ traz o assunto do início das matrículas públicas na rede de ensino, com informações sobre como proceder para realizar as inscrições. Quanto à sua diagramação, aparece disposta com duas fotos. Uma é a fachada da Central de Matrículas e outra apresenta Cátia Pereira, coordenadora municipal do órgão. Não há qualquer assinatura de repórter responsável pelo texto. É disposta em quatro parágrafos, todos com um intertítulo acima, além de um quadro explicando o passo a passo de como realizar as matrículas.

No primeiro parágrafo do texto, a Secretaria Estadual de Educação (Seduc), aparece como única fonte citada nominalmente, dizendo que em seu site as informações sobre os períodos de matrícula podem ser encontradas. Apenas no

terceiro parágrafo uma fonte volta a ser citada. Cátia Pereira é coordenadora municipal da Central de Matrículas da Secretaria de Educação e aparece falando sobre a 


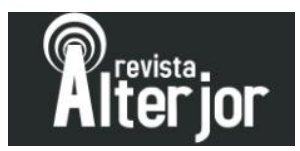

importância de garantir a vaga em uma escola. Neste mesmo parágrafo, o próprio órgão da Secretaria de Educação aparece como fonte novamente, explicando que o critério de designação dos alunos será por zoneamento. No quarto parágrafo, a secretaria volta a ser citada, ao falar da ficha de inscrição, que é encontrada no site do órgão.

Neste caso de texto jornalístico, publicado na edição conjunta de 31 de dezembro de 2018 e $1^{\circ}$ de janeiro de 2019, apenas duas fontes foram identificadas. Ao nos embasarmos nas definições de Lage (2009), ambas as fontes são consideradas oficiais, por serem mantidas pelo Estado, afinal uma das fontes é o próprio órgão estatal, aparecendo nominalmente, e a outra é uma funcionária deste órgão.

Lage (2009) define que as fontes oficiais são as mais confiáveis. Porém, não há fontes primárias, oferecendo dados ou versões, nem secundárias, que poderiam oferecer o contexto ambiental de preparação para uma primeira matrícula. Como as matrículas ainda não haviam testemunhos, mas poderiam também ser citados experts, uma vez que Lage (2009) os define também como fontes que podem ser secundárias, já que fornecem também versões e interpretações sobre o fato, neste caso, a importância de matricular uma criança na escola.

\begin{tabular}{|l|l|l|l|}
\hline Total de fontes & $\begin{array}{l}\text { Oficiais, oficiosas e } \\
\text { independentes }\end{array}$ & $\begin{array}{l}\text { Primárias } \\
\text { secundárias }\end{array}$ & $\begin{array}{l}\text { Testemunhas e } \\
\text { experts }\end{array}$ \\
\hline 2 & 2 - Oficiais & - & - \\
\hline
\end{tabular}

Tabela 1: Fontes encontradas na edição de 31 de dezembro de 2018 e $1^{\circ}$ de janeiro de 2019 do jornal Diário Popular

\section{5 dias decisivos para a safra de camarão - Sexta-feira, $1^{\circ}$ de fevereiro de 2019}

Neste dia, a edição impressa do Diário Popular trouxe em sua capa uma manchete destacando que a UPA da Avenida Bento Gonçalves seria utilizada para o atendimento pediátrico. Na foto de destaque, apontava que o Grêmio Esportivo Brasil seguia sem vencer no campeonato gaúcho após empate com o Juventude. 


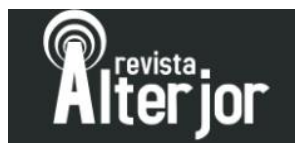

Em outro destaque, aparecia a nota alta de um aluno pelotense no vestibular. A matéria da página 3 surge junto de outros destaques em menor espaço, com a chamada "Safra se inicia longe da água”, seguido de duas linhas de explicação.

A matéria traz informações sobre o início da safra de camarão na Lagoa dos Patos, aberta oficialmente após o final do período de preservação, mas ainda sem a presença do crustáceo na água, o que preocupava os pescadores, que aguardavam melhorias ambientais para realizar seu trabalho.O texto jornalístico ${ }^{8}$ apresenta a chamada, seguida de linha de apoio, e sem assinatura de um repórter responsável pelo teto. Possui duas imagens. A em maior destaque, expõe as redes ainda parada à beira da lagoa. A segunda, do vice-presidente do Sindicato dos Pescadores, Sandro Manoel Pinto. O texto, dividido em 13 parágrafos, apresenta um intertítulo e um quadro sobre a fé e pedidos dos pescadores para melhorias climáticas através de festividades religiosas.

A primeira fonte aparece apenas no terceiro parágrafo. É o pescador Otavilino Costa Ortiz, afirmando que a categoria depende apenas das águas para conseguir pescar. Ele segue como a fonte do quarto parágrafo, ao ser citado em uma descrição sobre como estava a lagoa e a importância da água salgada adentrar a lagoa para a pescaria. No quinto parágrafo, a fonte também é citada, refletindo sobre o período de chuvas e no sexto, aparece novamente ao falar sobre as dificuldades do futuro da profissão. Já no sétimo parágrafo, uma segunda fonte é citada. Também é um pescador, Altemar Correia Donini, falando sobre o rigor da legislação atrapalhar a atividade. No oitavo, ele segue sendo citado, explicando como ocorrem perdas causadas por períodos de proibição na pesca, e no décimo, volta a ser citado, defendendo uma revisão nas leis.

Um intertítulo chamado Medidas aparece então, e na sequência, décimo primeiro parágrafo do texto, o Secretário de Desenvolvimento Rural de Pelotas, Jair Seidel, aparece falando sobre projetos de turismo e outras medidas para melhorar a vida financeira dos pescadores. No décimo segundo parágrafo, Sandro Manoel Pinto, vicepresidente do Sindicato dos Pescadores de Pelotas, aparece lamentando a situação da pesca e no décimo terceiro, continua, falando sobre mobilizações junto ao poder público para renegociar dívidas dos pescadores. Um quadro explicando sobre as festas 


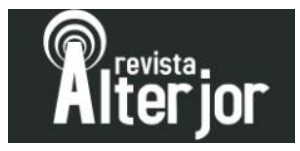

de Iemanjá e Nossa Senhora dos Navegantes aparece ao final do texto, com informações sobre os eventos, mas nenhuma fonte é citada neste espaço.

Neste caso de texto jornalístico, publicado na edição de $1^{\circ}$ de fevereiro de 2019, quatro fontes foram identificadas. O primeiro pescador citado, Otavilino Costa Ortiz, pode ser identificado como uma fonte primária a partir da premissa de Lage (2009), por ter oferecido a base essencial de qual é o problema enfrentado pelos pescadores. $\mathrm{O}$ segundo, Altemar Correia Donini, também entraria nessa categoria, por oferecer outra visão do problema, mas também uma base. Ambos não encaixam-se na figura do expert pois não atuaram na interpretação do evento, nem como especialistas no assunto, apenas como fornecedores de opiniões.

A terceira fonte citada, Jair Seidel, é uma fonte oficial na interpretação de Lage (2009), por aparecer como representante de um órgão público, neste caso, a Secretaria de Desenvolvimento Rural de Pelotas. A quarta fonte, Sandro Manoel Pinto, é um exemplo de fonte independente pela definição de Lage (2009), ao falar representando uma organização não-governamental, neste caso, um sindicato.

Neste texto, apesar de um aumento no número e na variação de fontes, percebese a falta de fontes secundárias, no papel de instituições de pesquisa que interpretem a questão climática por trás da ausência de água salgada na lagoa, podendo tal fator aparecer também através de experts, que interpretem a ligação entre a questão climática e as dificuldades financeiras dos pescadores. São várias fontes falando complementarmente, por vezes repetindo o que outra havia dito, enquanto nota-se a ausência desta figura especializada. Dessa maneira, o texto apresenta-se apenas como um grande diálogo e sem uma explicação objetiva sobre o motivo das dificuldades financeiras para os pescadores. Percebe-se que, para o leitor que não é familiarizado com as questões técnicas sobre uma pesca na Lagoa dos Patos, pode não ficar claro o motivo para o drama que os pescadores enfrentam. A necessidade de salgar, por exemplo, fica sem uma explicação, ou o motivo para as chuvas serem um impeditivo para o desenvolvimento dos camarões. 


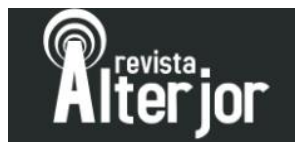

\begin{tabular}{|l|l|l|l|}
\hline Total de fontes & $\begin{array}{l}\text { Oficiais, oficiosas e } \\
\text { independentes }\end{array}$ & $\begin{array}{l}\text { Primárias } \\
\text { secundárias }\end{array}$ & $\begin{array}{l}\text { Testemunhas e } \\
\text { experts }\end{array}$ \\
\hline 4 & $\begin{array}{l}1-\text { Oficial } \\
1-\text { Independente }\end{array}$ & 2 - Primárias & - \\
\hline
\end{tabular}

Tabela 2: Fontes encontradas na edição de $1^{\circ}$ de fevereiro de 2019 do jornal Diário Popular

\section{A força da mulher para ajudar o próximo - Sexta-feira, $1^{\circ}$ de março de 2019}

Esta edição do Diário Popular trazia nos destaques da capa as linhas de ação na segurança pública, apresentadas pelo Estado. A inauguração do Restaurante Universitário do Campus Anglo da Universidade Federal de Pelotas (UFPel) foi a imagem de destaque. Entre as chamadas com menor destaque, matérias sobre o carnaval, novas agroindústrias no município e mudanças no jockey clube de Pelotas. $\mathrm{O}$ texto da página 3 também é destaque, em uma foto menor no topo da página, com a chamada “Exemplo e lição de vida”, seguida de duas linhas explicando a matéria.

O texto, intitulado A força da mulher para ajudar ao próximo, faz parte de uma série especial sobre o Dia Internacional da Mulher, celebrado em 8 de março. O Diário Popular contou, neste período, diversas histórias sobre mulheres de Pelotas que fazem diferença em setores da sociedade. Neste dia, foi trazida a história da centenária Ana Maria $\operatorname{Costa}^{3}$, envolvida em causas sociais em boa parte de sua vida.

O texto ${ }^{4}$ é assinado por Júlia Müller e apresenta-se dividida em sete parágrafos, além de contar com um quadro lateral com outros quatro parágrafos. Traz uma imagem principal, de Ana Maria Costa costurando, além de uma foto de um coração bordado por ela e de um logo que identifica a série especial do Dia Internacional da Mulher.

Logo no primeiro parágrafo, Ana Maria Costa já aparece citada, falando sobre seu trabalho político, social e enquanto professora. O texto é descritivo, ambientando sobre o momento em que a entrevista é realizada. No segundo parágrafo, também é a

\footnotetext{
3 O texto explica, em sua introdução, que Ana Maria Costa foi secretária municipal de Educação, professora de séries iniciais e que hoje atua como voluntária na Associação Pioneiras do Bem.

4 Disponível em: h ttps://www.diariopopular.com.br/geral/centenaria-empenhada-no-voluntariado$139261 /$ ?
} 


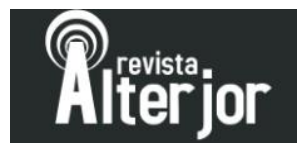

única pessoa citada, ao falar sobre o centenário e a vida de professora. No terceiro, outra senhora, Nilda Pinheiro, é citada, apresentada como membro da Associação Pioneiras do Bem. Ela fala sobre o trabalho da Associação Pioneiras do Bem, um grupo de voluntárias para causas sociais localizado na praia do Laranjal, em Pelotas. O quarto parágrafo fala sobre o Instituto Buquê do Amor, instituição de apoio às mulheres e parceira da Associação, mas sem uma citação clara da fonte, mas deixando a impressão de que Nilda Pinheiro é quem fala, já que o parágrafo anterior encerra com ela falando sobre a parceria entre as duas instituições.

O quinto parágrafo continua com Nilda Pinheiro falando sobre as atividades realizadas pelas Pioneiras do Bem. Já o sexto parágrafo retorna para Ana Maria Costa, que conta sobre sua atuação em conjunto com as companheiras de Associação. Já o sétimo parágrafo traz reflexões sobre a vida centenária a partir da visão de Ana Maria Costa e conta sobre como ela juntou-se ao grupo.

$\mathrm{Na}$ sequência, um quadro informativo de quatro parágrafos aparece. No primeiro, Ana Maria Costa continua sendo fonte única, ao falar sobre ser uma mulher independente, mesmo em um passado onde isso não era tão aceito pela sociedade. Já no parágrafo seguinte, embora continue com frases da entrevistada, há uma referência ao Instituto Brasileiro de Geografia e Estatística sobre a média de idade na qual as mulheres se casavam nos anos 70. Os dois últimos parágrafos do texto continuam com a entrevistada falando sobre sua vida e temas como maternidade, vida política e atividades de lazer realizadas por ela.

Neste texto jornalístico podem ser identificadas três fontes citadas. A primeira, Ana Maria Costa, personagem central do texto, encaixa-se como fonte primária, por fornecer os fatos e versões que fundamentam grande parte do texto, como sugere a premissa de Lage (2009). Já Nilda Pinheiro, embora possa parecer uma fonte independente pelas definições de Lage (2009), ao falar como membro da Associação Pioneiras do Bem, pode-se encaixar melhor enquanto fonte secundária, já que suas falas aparecem mais enquanto contextualizadoras do ambiente do que oferecendo posicionamentos em nome da Associação. A citação da instituição aparece em um contexto de localizar ela dentro das relações da personagem do texto, mas não como 


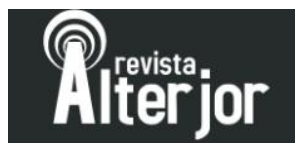

uma porta voz da organização. A terceira fonte é claramente oficial, a partir do mapeamento de Lage (2009) que inclusive cita o próprio órgão enquanto exemplo de fonte oficial.

Analisando as disposições das fontes no texto, talvez uma fonte independente, ligada à direção da Associação, pudesse vir a ser utilizada, embora uma fonte secundária acabe exercendo o mesmo papel. A figura da testemunha também poderia, em algum maneira, aparecer, enquanto personagem ajudado pelas ações sociais de Ana Maria Costa. Porém, percebe-se também que em nenhum momento o texto encaminhouse para essa situação, voltando-se mais à história de vida da personagem central e a façanha de manter-se ativa em trabalhos sociais mesmo com idade tão avançada.

\begin{tabular}{|l|l|l|l|}
\hline Total de fontes & $\begin{array}{l}\text { Oficiais, oficiosas e } \\
\text { independentes }\end{array}$ & $\begin{array}{l}\text { Primárias } \\
\text { secundárias }\end{array}$ & $\begin{array}{l}\text { Testemunhas e } \\
\text { experts }\end{array}$ \\
\hline 3 & 1 - Oficial & $\begin{array}{l}1-\text { Primária } \\
1-\text { Secundária }\end{array}$ & - \\
\hline
\end{tabular}

Tabela 3: Fontes encontradas na edição de $1^{\circ}$ de março de 2019 do jornal Diário Popular

\section{UFPel aguarda recursos para iniciar obras no Grande Hotel - Segunda-} feira, $1^{\circ}$ de abril de 2019

Nesta edição do Diário Popular, a capa trazia, enquanto sua manchete, a luta de portadores de fibromialgia por direitos. A foto menor, ao lado da manchete, destacava a ação de uma ONG para adoção de animais. Outras situações. como a primeira vitória do Grêmio Atlético Farroupilha na divisão de acesso do campeonato gaúcho de futebol, um reajuste no preço dos remédios e o aniversário de uma associação que atua na praia do Laranjal também receberam destaques na capa. O tema da página 3 é também a foto principal, ocupando boa parte do espaço da capa, com a chamada " $A$ espera de recursos", seguida de seis linhas curtas explicando um pouco da situação na sequência. 


\section{Aterior}

O tema deste ${ }^{5}$ texto jornalístico é o aguardo da Universidade Federal de Pelotas por recursos provenientes do Instituto do Patrimônio Histórico e Artístico Nacional para a reforma do prédio do Grande Hotel $^{6}$. Assinado pelo repórter Roberto Giovanaz, é constituído por sete parágrafos, divididos por dois intertítulos. Há também um quadro com a linha do tempo da reforma do Grande Hotel. É apresentado com duas imagens, uma foto maior, da parte interna do prédio, e uma foto menor, de Otávio Peres, pró-reitor de Planejamento e Desenvolvimento da Universidade Federal de Pelotas.

Já no primeiro parágrafo, o secretário especial de Cultura do Ministério da Cidadania, Henrique Pires, aparece como fonte da informação ao garantir R \$ 9 milhões para a reforma do Grande Hotel. Na sequência deste parágrafo, a Pró-Reitoria de Planejamento e Desenvolvimento da Universidade Federal de Pelotas aparece citada, assim como a própria Universidade, mas nenhuma como fonte de informação. No segundo parágrafo, o Reitor Pedro Curi Hallal e Henrique Pires também são citados, mas também, não como fontes. Um desejo da Reitoria e um pedido de informações da Pró-Reitoria também são citados, mas sem uma fonte clara da procedência das informações. A partir do terceiro parágrafo, Otávio Peres, pró-reitor responsável pela pasta citada anteriormente, aparece falando sobre o pedido do recurso. No parágrafo seguinte, que inicia após um intertítulo, Otávio Peres segue sendo citado. Na sequência, um diálogo entre uma estudante e uma vigilante aparece, mas sem o nome de ambas, em uma conversa sobre as expectativas para a reforma. $\mathrm{O}$ sexto e sétimo parágrafos aparecem após novo intertítulo, mas apenas com Otávio Peres sendo citado, ao falar sobre as atividades que serão realizadas no prédio após a reforma. $\mathrm{O}$ texto é encerrado com uma linha do tempo, na qual diversas instituições públicas são citadas, mas nenhuma enquanto fonte, apenas citando ações tomadas por tais órgãos.

\footnotetext{
${ }^{5}$ Disponível em: https://www.diariopopular.com.br/geral/ufpel-aguarda-recursos-para-iniciar-obras-nogrande-hotel-14 0039/?

${ }^{6} \mathrm{O}$ Grande Hotel é um prédio histórico da região central de Pelotas, que por muito tempo foi, de fato, Hotel, até seu fechamento. Foi doado ao município e, em 2012, repassado à UFPel, destinado a um hotelescola.
} 


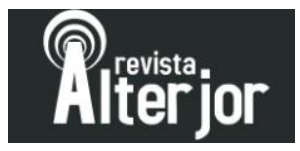

Pode-se perceber que pelo menos quatro fontes são citadas diretamente no texto, sendo Henrique Pires, Otávio Peres, além da estudante e da vigia que dialogam. Neste texto, destaca-se que foram citadas diversas instituições públicas, mas são mencionadas apenas enquanto personagens da história, sem ficar claro se a informação provém de notas oficiais, documentos, ou se foram citadas de alguma maneira pelas fontes presentes no texto. Pode-se perceber que o autor faz um apanhado histórico em diversos momentos, deduzindo-se que ele utilizou-se de arquivos para relembrar o passo a passo, mas em nenhum momento isso fica claro. Percebe-se que muitas vezes, por falta de tempo ou pela dificuldades em encontrar informações documentais claras, o jornalista pode recorrer a arquivos e informações publicadas em edições anteriores do próprio jornal onde trabalha, e muitas vezes, isso não fica claro nos textos. Lage (2009) sustenta que este tipo de fonte, por vezes, acaba não sendo citada pelo jornalista ao decorrer do texto.

Ao mapear as fontes pelas definições apresentadas por Lage (2009) pode-se perceber que, neste caso, uma fonte aparece fazendo duas funções. Em dado momento, Otávio Peres é citado como fonte oficial ligada à Universidade Federal de Pelotas, fornecendo a posição do órgão. Em outro, no entanto, ele aparece enquanto fonte primária, por fornecer fatos e versões. Neste caso, ele será tabelado duas vezes, já que é uma fonte que executa múltiplos papéis ao longo do texto. O também citado Henrique Pires é mapeado, a partir das definições de Lage (2009) enquanto fonte oficial, já que oferece o posicionamento de um órgão público, neste caso, uma secretaria do governo. As outras duas pessoas que aparecem, embora não citadas, podem ser identificadas na premissa de Lage (2009) enquanto fontes secundárias, já que oferecem ao texto um diálogo no contexto ambiental do aguardo pelas obras.

Pode-se discutir a falta de testemunhas, pessoas que ofereçam o contexto de viver a realidade de um prédio com problemas estruturais, pois os alunos da Hotelaria, além de conviverem com o prédio, devem possuir histórias ligadas ao testemunho de problemas causados pela estrutura precária. Parece também faltar fontes experts, partindo de especialistas em educação ou hotelaria, sobre como a falta de estrutura interfere na questão estudantil, ou mesmo de um estudante falando sobre a expectativa 


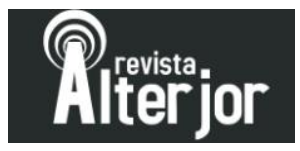

por estudar hotelaria em um espaço histórico, que poderia aparecer enquanto fonte primária, enquanto fornecedor de versão pela definição de Lage (2009). Cabe-se salientar, porém, que apesar de diversos momentos as fontes não estarem claras, o texto visava informar a expectativa pela reforma do espaço, e pode-se dizer que isso ficou claro.

\begin{tabular}{|l|l|l|l|}
\hline Total de fontes & $\begin{array}{l}\text { Oficiais, oficiosas e } \\
\text { independentes }\end{array}$ & $\begin{array}{l}\text { Primárias } \\
\text { secundárias }\end{array}$ & $\begin{array}{l}\text { Testemunhas } \\
\text { e experts }\end{array}$ \\
\hline $\begin{array}{l}4 \text { (uma fonte faz dois } \\
\text { papéis) }\end{array}$ & 2 - Oficiais & $\begin{array}{l}1 \text { - Primária } \\
2 \text { - Secundárias }\end{array}$ & - \\
\hline
\end{tabular}

Tabela 4: Fontes encontradas na edição de $1^{\circ}$ de abril de 2019 do jornal Diário Popular

\section{Tarifa de R\$ 3,70 para todo o município - Quarta-feira, $1^{\circ}$ de maio de 2019 e quinta-feira, 2 de maio de 2019}

Esta edição do Diário Popular foi conjunta em virtude do feriado em $1^{\circ}$ de maio. Nesta data, os destaques da capa foram uma manchete sobre quatro empresas estarem disputando o restauro do Theatro Sete de Abril, as metas da Santa Casa para lidar com o déficit financeiro, as partidas do Campeonato Brasileiro de Futebol, o dissídio dos municipários e, como foto principal da capa, o item da página 3. Com a chamada " $O$ ir e vir da Zona Rural ", apresenta uma explicação em seis linhas curtas, e uma foto de um ônibus em uma estrada rural, destacando o preço da tarifa. Este texto jornalístico ${ }^{13}$, assinado por Roberto Giovanaz, destacava o início do novo valor da tarifa no transporte coletivo rural, se igualando ao valor do transporte coletivo urbano. É apresentado em oito parágrafos divididos por quatro intertítulos, com duas imagens. A primeira, em maior destaque, mostra um ônibus próximo a uma placa mostrando localidades da Zona Rural de Pelotas, e a segunda destaca a identificação do novo valor, de $\mathrm{R} \$ 3,70$, na frente de um ônibus. Já no primeiro parágrafo, a prefeita de Pelotas, Paula Mascarenhas, aparece citada, celebrando o momento histórico. O segundo parágrafo traz informações 


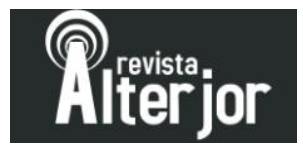

de valores no formato anterior de cobrança, mas sem a citação de uma fonte direta. No terceiro parágrafo, a prefeita reaparece enquanto fonte, citando o processo de mudança na legislação e os frutos esperados dessa atitude. No quarto parágrafo, após intertítulo, surgem informações sobre como a modalidade irá funcionar, mas sem fontes claras da procedência dos dados. No parágrafo seguinte, a prefeita reaparece falando sobre o subsídio da prefeitura para as passagens. Após a fala dela, o secretário Municipal de Trânsito, Flávio Al Alam, é citado, falando sobre a satisfação e o processo de implementação do novo tipo de transporte rural.

Um novo intertítulo abre o sexto parágrafo, que fala sobre as mudanças das linhas, mas novamente sem apontar a fonte de informação. Após outro intertítulo, o secretário de Desenvolvimento Rural, Jair Seidel, é mencionado, falando sobre a importância da iniciativa para permanência do trabalhador rural no campo. No último parágrafo, aberto por mais um intertítulo, dois usuários do transporte coletivo rural são citados. Sandra Iara Lettnin e Carlos Eduardo Ziebell, aparecem aprovando a iniciativa, ela citando a economia pela nova modalidade de cobrança e ele quanto à facilidade para utilizar o serviço.

Neste texto jornalístico, ficam claras cinco fontes de informação. A prefeita de Pelotas, Paula Mascarenhas, além dos dois secretários municipais, Flávio Al Alam e Jair Seidel, além dos dois usuários, citados no último parágrafo.

Pelas definições de Lage (2009), os três primeiros podem ser considerados fontes oficiais, já que são citados no texto a partir de sua atuação em órgãos governamentais. Já os dois usuários aparecem enquanto fontes secundárias, pois oferecem as premissas genéricas do usuário e a ambientação da vivência de ser um morador da Zona Rural e serem beneficiados com o novo formato de cobranças de tarifas do transporte público.

Pode-se perceber que o repórter optou, então, por usar diversas fontes, mas de apenas duas naturezas a partir do mapeamento de Lage (2009). Refletindo sobre essa escolha, pode perceber-se que foi feita a opção em apenas citar o lançamento a partir da ótica oficial e do usuário, ou seja, a fonte secundária. Percebe-se a falta de explicação 


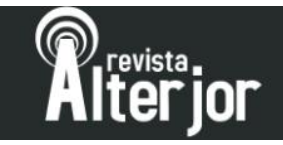

para a mudança, que poderia ter sido apresentada por um expert pela definição de Lage (2009), que nesse contexto poderia atuar explicando os motivos da diferença até então cobrada no valor do transporte coletivo rural, e como isso afetou ao longo do tempo os trabalhadores daquelas regiões, ou então de uma fonte independente, a partir da ótica dos trabalhadores do transporte, para verificar se para eles haverá alguma alteração.

\begin{tabular}{|l|l|l|l|}
\hline Total de fontes & $\begin{array}{l}\text { Oficiais, oficiosas e } \\
\text { independentes }\end{array}$ & $\begin{array}{l}\text { Primárias e } \\
\text { secundárias }\end{array}$ & $\begin{array}{l}\text { Testemunhas } \\
\text { e experts }\end{array}$ \\
\hline 5 & 3 - Oficiais & 2 - Secundárias & - \\
\hline
\end{tabular}

Tabela 5: Fontes encontradas na edição de $1^{\circ}$ e 2 de maio de 2019 do jornal Diário Popular

\section{Hospital-Escola volta a oferecer radioterapia - Sábado, $1^{\circ}$ de junho de 2019 e domingo, 2 de junho de 2019}

Nesta edição conjunta do Diário Popular, que circulou em dois dias por ser um final de semana, a manchete principal era sobre o início da próxima edição da Fenadoce, marcado para aquela semana. Outras matérias, como a final da Liga dos Campeões da Europa, uma feira de artesanato, uma história sobre Yolanda Pereira, ex-Miss Universo e uma venda de veículos do governo do Estado eram destaques. A matéria da página 3 foi destaque como foto principal da capa, com o texto "O fim da espera", seguido de seis linhas explicativas.

Este texto aborda o retorno do serviço de radioterapia ao Hospital-Escola da Universidade Federal de Pelotas ${ }^{14}$. Assinado por Roberto Giovanaz, é dividido em oito parágrafos, com dois intertítulos e duas imagens. Em maior destaque, uma delas ilustra a sala do Serviço de Oncologia do Hospital lotada. Na outra, localizada em menor tamanho no canto inferior direito, aparece um equipamento e, ao fundo, um grupo de pessoas.

O texto é aberto com uma citação do Reitor da Universidade Federal de Pelotas, Pedro Curi Hallal, falando sobre os serviços prestados pela instituição à sociedade. $\mathrm{O}$ 


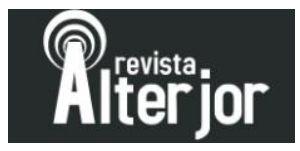

parágrafo continua com informações sobre o novo acelerador linear que proporcionará o uso das radioterapias na Hospital-Escola da Universidade Federal de Pelotas. Em dado momento, são citadas as diversas autoridades presentes comemorando a conquista, mas sem nenhum nome específico mencionado.

O segundo parágrafo inicia explicando como o aparelho irá operar. A superintendente do Hospital-Escola, Samanta Madruga, é citada, falando sobre como era prestado o serviço anteriormente. No terceiro parágrafo, ela continua falando sobre a operacionalidade do equipamento. O quarto parágrafo, com poucas linhas, menciona o trabalho feito para adquirir o acelerador, sem citar fontes.

A partir do quinto parágrafo, aberto com intertítulo, Pedro Hallal volta a aparecer como fonte, falando sobre os diferentes trabalhos da universidade para a sociedade. No sexto, o secretário de Saúde de Pelotas, Leandro Thurow, é citado, ao falar sobre a demanda do serviço no município e a importância de aumentar o serviço radioterápico na região. Após novo intertítulo, é citado Marcelo Capilheira, aparecendo como o diretor. $\mathrm{O}$ texto não deixa claro o órgão que ele dirige ${ }^{15}$, mas cita-o falando sobre a expectativa de aumento nos casos de câncer com o envelhecimento da população. No último parágrafo do texto, Marcelo Capilheira continua sendo a fonte, ao falar sobre o benefício do novo setor para os estudantes da Universidade.

Portanto, ao analisar o texto, ficam claras quatro fontes. Pela ótica de Lage (2009) o Reitor Pedro Curi Hallal é uma fonte oficial, ao falar enquanto representante de um órgão. Samanta Madruga, superintendente do Hospital-Escola, embora também pronuncie-se enquanto representante de órgão oficial, pode ser vista como uma fonte primária, pois fornece versões, fatos e números sobre a atuação do Hospital, três dos pilares de Lage (2009) para uma fonte primária.

Das outras fontes citadas, Leandro Thurow também pode ser visto como uma fonte oficial, pois fala e nome de um órgão governamental, dando a versão de uma instituição quanto à necessidade de expandir o serviço radioterápico. Marcelo Capilheira, ao falar enquanto diretor da Faculdade de Medicina, pode ser visto como um expert a partir das premissas de Lage (2009). Mesmo que ele esteja representando uma 


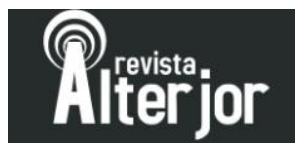

instituição, sua fala na entrevista é apresentada enquanto interpretante dos benefícios de ter o retorno do tratamento radioterápico no Hospital-Escola.

Ao analisar o uso das fontes, pode-se perceber que todas, de alguma maneira, estão ligadas a alguma instituição oficial, embora não falem necessariamente neste sentido. Não há, por exemplo, a figura secundária, que Lage (2009) define como construtor de premissas genéricas ou ambientais. Neste caso, poderia aparecer de diversas maneiras. Um estudante que utilizará o espaço para aprendizado, um dos motivos para a implementação, segundo a reportagem, através de um paciente, que receberia o tratamento ou até mesmo de um funcionário, que passará a atuar nesse novo setor. Em nenhum momento o texto apresenta a possibilidade de fazer uso de fontes independentes, portanto, a ausência delas não afeta o texto final, e a presença de testemunhas também não parece se encaixar no contexto, uma vez que o texto passa a clareza de que o próprio repórter esteve presente no ato de inauguração, ao trazer falas de discursos oficiais, como o do Reitor.

\begin{tabular}{|l|l|l|l|}
\hline Total de fontes & $\begin{array}{l}\text { Oficiais, oficiosas e } \\
\text { independentes }\end{array}$ & $\begin{array}{l}\text { Primárias e } \\
\text { secundárias }\end{array}$ & $\begin{array}{l}\text { Testemunhas } \\
\text { e experts }\end{array}$ \\
\hline 4 & 2 - Oficiais & 1 - Secundária & 1 - Expert \\
\hline
\end{tabular}

Tabela 6: Fontes encontradas na edição de $1^{\circ}$ e 2 de junho de 2019 do jornal Diário Popular

\section{Praça Piratinino de Almeida de cara nova - Segunda-feira, $1^{\circ}$ de julho de 2019}

Esta edição impressa do Diário Popular traz como manchete principal a notícia de que menos de $1 \%$ dos pelotenses vivem sem rede de água. Dentre as outras chamadas, os jogos da Copa América de Futebol, o aniversário da cidade, notícias sobre as equipes de futebol do Grêmio Esportivo Brasil e do Esporte Clube Pelotas, duas mortes no bairro Lindoia e que a cidade recebeu o prêmio máximo do Nota Fiscal Gaúcha. O tema da página 3 foi a foto principal da capa, com a chamada "Uma praça mais verde", seguida de quatro linhas explicativas. 


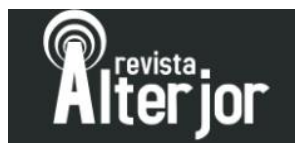

O texto, com assinatura de Júlia Müller, aborda o processo de requalificação da Praça Piratinino de Almeida, na região central da cidade, que naquele momento recebia a última etapa de intervenções, com melhorias na vegetação e canteiros. É disposta com uma foto, mostrando pessoas caminhando pela praça. É dividida em sete parágrafos, contendo um intertítulo, além de uma linha do tempo com a história do local. ${ }^{16}$

Este texto jornalístico começa versando sobre as etapas da obra de reforma da praça Piratinino de Almeida e os órgãos responsáveis pelo serviço. Apesar de citar duas pastas municipais, nenhuma aparece enquanto fonte. Elas apenas aparecem enquanto responsáveis, mas sem nada que remeta à origem da informação. $\mathrm{O}$ segundo parágrafo traz uma fala do arquiteto e urbanista responsável, Fernando Sparenberg, explicando alguns detalhes do projeto. No terceiro parágrafo, o arquiteto continua sendo a fonte entrevistada, sendo ressaltado que ele é funcionário da secretaria de Qualidade Ambiental do município. Neste espaço, ele fala sobre a terceira e última etapa de obras e os motivos para algumas iniciativas tomadas. Neste parágrafo, a própria secretaria de Qualidade Ambiental aparece como fonte, a partir de um levantamento quanto à arborização do local.

No quarto parágrafo, o arquiteto retorna, explicando os cuidados quanto à realização de reformas em um espaço histórico. Neste mesmo parágrafo, o diretorpresidente do Serviço Autônomo de Saneamento de Pelotas, Alexandre Garcia, aparece também como fonte ao divulgar os custos da reforma, que foram de R \$177 mil. Após intertítulo, o quinto parágrafo do texto continua com informações do órgão presidido por Alexandre Garcia, quanto à reforma do reservatório de água presente na praça. No sexto parágrafo, ele continua falando sobre a procura de empresas para realizar estudos quanto à possibilidade de utilizar o reservatório novamente. No sétimo parágrafo, fala-se sobre a reforma do reservatório, com financiamento feito pelo Instituto do Patrimônio Histórico e Artístico Nacional. O órgão, porém, não aparece enquanto fonte em nenhum momento. No quadro com linha do tempo falando sobre a história da praça Piratinino de Almeida, que encerra o texto, nenhuma fonte é citada claramente. 


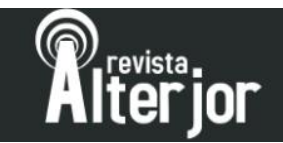

Pode-se perceber, então, que este texto deixa claro o uso de três fontes. O arquiteto e urbanista ligado à secretaria de Qualidade Ambiental, Fernando Sparenberg, mesmo falando enquanto representante de órgão público, pode ser visto, a partir das definições de Lage (2009) como um expert, já que traz versões e interpretações do evento, que neste caso, é a reforma da praça. Lage (2009) inclusive ressalta que experts podem, por vezes, ser fontes secundárias, justamente por fornecer versões. No entanto, optou-se mapear ele enquanto expert, por, nas definições de Lage (2009), este tipo de fonte ser a responsável por versões ou interpretações, justamente a atuação dele neste caso. A secretaria de Qualidade Ambiental, citada no texto como referência para uma pesquisa feita por ela, é o típico caso de fonte oficial na premissa de Lage (2009), uma vez que é o posicionamento de um órgão governamental. Alexandre Garcia, a terceira fonte presente, apesar de ser uma fonte oficial, já que é o representante máximo de um órgão governamental, poderia ser também uma fonte primária, pois oferece números, versões e fatos. Optou-se, então, por novamente, mapear uma fonte em duas categorias, pois ele exerce ambos papéis no texto.

Neste texto jornalístico, é pertinente questionar a ausência de fontes secundárias, que Lage (2009) define que são usadas no papel de construção de premissas genéricas e contextos ambientais, podendo aparecer enquanto usuários da praça. Nota-se também a ausência de fontes do tipo testemunha, que pelo mapeamento de Lage (2009) poderiam ter aparecido enquanto moradores da região, em um momento, no terceiro parágrafo, quando o texto fala sobre o local ser utilizado para usos de substâncias ilícitas e prostituição. Não há qualquer posicionamento quanto aos moradores que vivenciam estes fatos.

\begin{tabular}{|l|l|l|l|}
\hline Total de fontes & $\begin{array}{l}\text { Oficiais, oficiosas e } \\
\text { independentes }\end{array}$ & $\begin{array}{l}\text { Primárias } \\
\text { secundárias }\end{array}$ & $\begin{array}{l}\text { Testemunhas e } \\
\text { experts }\end{array}$ \\
\hline $\begin{array}{l}3 \text { (uma fonte faz dois } \\
\text { papéis) }\end{array}$ & 2 - Oficiais & 1 - Secundária & 1 - Expert \\
\hline
\end{tabular}

Tabela 7: Fontes encontradas na edição de $1^{\circ}$ de julho de 2019 do jornal Diário Popular 


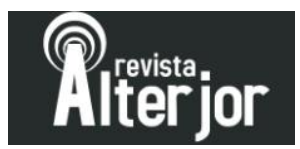

\section{Amamentação, agora e no futuro - Quinta-feira, $1^{\circ}$ de agosto de 2019}

Nesta edição impressa do Diário Popular, a manchete da capa estampava a informação de que as instituições federais de ensino do município estavam sem recursos em caixa devido aos bloqueios orçamentários. Um show na Bibliotheca Pública de Pelotas e as partidas de Grêmio e Internacional pela Copa Libertadores da América também eram destaques. $\mathrm{O}$ tema da página 3 era a foto principal desta capa, mostrando uma mulher amamentando e a chamada "Um ato para toda a vida", seguido de quatro linhas explicativas.

O texto jornalístico ${ }^{17}$, com assinatura de Marina Amaral, foi dividido em quatro parágrafos, além de dois quadros explicativos com um parágrafo cada. Com uma única foto, mostrava uma mulher amamentando e olhando seu bebê. A temática da reportagem era justamente o primeiro dia da Semana Mundial do Aleitamento Materno, seguida de sua programação.

Em sua primeira linha, o texto já cita duas fontes, a Organização Pan-Americana da Saúde e a Organização Mundial da Saúde, com suas recomendações quanto à amamentação. O parágrafo continua citando outras organizações, mas com informações à partir da Organização Mundial da Saúde. Em seu encerramento, informa que o Ministério da Saúde abriu de forma oficial as comemorações alusivas à data do Agosto Dourado $^{18}$.

No segundo parágrafo, a professora da Universidade Católica de Pelotas, Luisa Jardim de Oliveira, é apresentada em uma fala que explica a importância da data e os benefícios de políticas públicas que incentivem o aleitamento materno. O terceiro parágrafo continua com a professora contando quais atividades seriam feitas naquele mês para incentivar a amamentação, citando diversas instituições, mas sendo ela mesma a fonte das informações.

A partir do quarto parágrafo, a reportagem traz informações a partir da Secretaria de Saúde do município, que divulgou as informações de eventos em espaços 


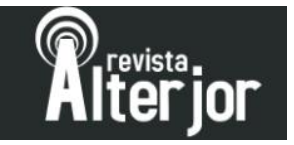

públicos que incentivassem a amamentação. Este parágrafo também cita um evento na Universidade Católica de Pelotas, mas percebe-se que a referência de fonte continua sendo a divulgação do órgão da prefeitura. O parágrafo é, então, encerrado trazendo informações da Secretaria Estadual da Saúde, sobre atividades voltadas aos profissionais da saúde.

No primeiro quadro presente na matéria, o texto traz o depoimento de Ariane Gomez de la Fuente, mãe de um recém nascido, falando sobre a importância de amamentar e a conexão criada entre eles a partir desse momento. O segundo quadro traz o resultado de pesquisas, sem citar o órgão responsável, de que a amamentação tem a capacidade de reduzir em $13 \%$ a mortalidade infantil. Ele continua com a informação de que a Universidade Federal de Pelotas, a partir do Centro de Epidemiologia, possui estudos que mostram a importância da prática no desenvolvimento infantil. O texto segue, então, trazendo alguns dos apontamentos deste estudo.

Neste texto jornalístico podem ser identificadas um total de nove fontes diferentes. Ao aparecerem juntas na introdução, a Organização Pan-Americana de Saúde e a Organização Mundial da Saúde realizam o mesmo papel a partir das definições de Lage (2009), atuando enquanto fontes primárias que oferecem fatos e versões sobre a necessidade da amamentação. O texto traz também o posicionamento do Ministério da Saúde, Secretaria Municipal da Saúde e Secretaria Estadual da Saúde. As três fontes, que fazem o mesmo papel ao falar de suas ações para incentivar o mês de incentivo ao aleitamento materno, aparecem enquanto fontes oficiais ao mapearmos pelas premissas de Lage (2009), já que trazem o posicionamento de órgãos governamentais.

Ao citar a professora da Universidade Católica de Pelotas, Luisa Jardim de Oliveira, o texto traz a visão de uma fonte que é mapeada por Lage (2009) como expert, já que ela atua na interpretação de algo, neste caso, das políticas públicas para a amamentação. A presença da mãe de um recém nascido, Ariane Gomez de la Fuente, é o caso de fonte secundária segundo define Lage (2009), pois ela é apresentada no texto 


\section{Preiejer}

fornecendo um contexto ambiental. Por fim, a repórter traz dois estudos. Embora um seja apresentado sem citar fonte, Lage (2009) diz que é algo comum quando tratam-se de informações obtidas junto a órgãos oficiais, portanto, será categorizado como oficial. O segundo estudo foi realizado pela Universidade Federal de Pelotas, acaba sendo uma fonte primária, por também trazer dados e versões que fundamentam o texto.

Cabe-se destacar a pluralidade de fontes em abundância neste texto. Embora não exista nenhuma fonte do tipo testemunha, a presença da mãe, enquanto fonte secundária, também realiza, de certo modo, esse papel. Há um grande número de fontes oficiais, mas isso se dá por citar organizações de saúde de diversas esferas.

\begin{tabular}{|l|l|l|l|}
\hline Total de fontes & $\begin{array}{l}\text { Oficiais, oficiosas e } \\
\text { independentes }\end{array}$ & $\begin{array}{l}\text { Primárias } \\
\text { secundárias }\end{array}$ & $\begin{array}{l}\text { Testemunhas e } \\
\text { experts }\end{array}$ \\
\hline 9 & 4 - Oficiais & $\begin{array}{l}3 \text { - Primárias } \\
1-\text { Secundária }\end{array}$ & 1 - Expert \\
\hline
\end{tabular}

Tabela 8: Fontes encontradas na edição de $1^{\circ}$ de agosto de 2019 do jornal Diário Popular

Fora dos muros da escola e dentro do cotidiano da sociedade - Sábado, 31 de agosto de 2019 e domingo, $1^{\circ}$ de setembro de 2019

Esta edição conjunta do Diário Popular, por se tratar de um final de semana, traz como destaque na capa uma manchete que informa o valor do prédio da Câmara de Vereadores, avaliado em $\mathrm{R} \$ 4,5$ milhões. A imagem principal da capa leva para o caderno Estilo, da editoria de Cultura, que fala sobre o resgate de cartas por um grupo de pesquisadores. Outras informações, como as partidas de futebol envolvendo Grêmio Esportivo Brasil e Esporte Clube Pelotas, um assalto na região, mudanças editoriais do jornal em virtude da comemoração de seu aniversário, um projeto para tombamento do Theatro Avenida, além de destaques de colunistas, são anunciados na capa. O tema da página 3 não aparece nas chamadas. 


\section{Preiejer}

O texto jornalístico é assinado por Roberto Giovanaz ${ }^{19}$ e é apresentado com duas imagens, de uma menina segurando um copo e um canudo, essa foto em maior destaque, e a segunda, com uma menina e um senhor sentados. O texto subdivide-se em oito parágrafos, com um intertítulo, além de um quadro informativo presente ao final. A temática da matéria é a criação de um canudinho biodegradável a partir do uso de celulose, iniciativa de uma menina de 14 anos, estudante do colégio LaSalle de Pelotas. A criação dela obteve destaque nacional.

Já no primeiro parágrafo, é apresentada Biatrice de Leon Cantaluppi, de 14 anos, como autora da ideia, junto do professor de Biologia, Vinicius Vargas de Castro. O segundo parágrafo aponta diversas feiras nas quais o trabalho foi ou seria exposto, mas em nenhum momento há a citação de uma fonte clara. $\mathrm{O}$ terceiro parágrafo fala da origem da ideia, partindo de um projeto em aula, mas, também, sem a citação de uma fonte clara.

Já no quarto parágrafo, retorna à iniciativa da estudante, que conta como chegou a conclusão de criar o projeto. Após intertítulo, o quinto parágrafo traz a ideia na prática, novamente sem citar nomes, mas deixando claro que é uma explicação da aluna, revelando que ela batizou o canudo biodegradável de Celudinho. $\mathrm{O}$ texto retorna ao professor, que fala exaltando o orgulho da aluna. No parágrafo seguinte, Biatrice reaparece, falando sobre o evento que participou e, por fim, projeta a vida futura, a partir do desejo de ser uma pesquisadora científica. O quadro explicativo na sequência elucida o funcionamento da legislação que proíbe canudos de plástico em Pelotas, mas não traz informações quanto a fontes.

Neste texto jornalístico, apenas duas fontes aparecem claramente fornecendo informações. Somente a aluna Biatrice de Leon Cantaluppi e o professor Vinicius Vargas de Castro são mencionados. Pelas premissas de Lage (2009), ambos podem ser considerados fontes primárias, pois foram a base utilizadas pelo jornalista para fornecer fatos, versões e números. 


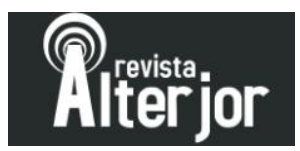

Cabe-se destacar que Lage (2009) diz que fontes oficiais por vezes surgem nos textos sem serem citadas, como pode ser o caso dos eventos, mas não fica claro se a versão sobre eles que conta no texto partiu de mensagens oficiais ou dos dois entrevistados. Percebe-se também a falta de, pelo menos, uma fonte expert explicando a legislação, ou uma fonte secundária que já utilize de canudos biodegradáveis. Mas, como o contexto do texto jornalístico é contar a história da menina, o autor do texto pode ter avaliado que seria melhor focar apenas nisso. No entanto, fontes múltiplas são importantes para dar um contexto maior. Dessa maneira, oferecem outras versões e interpretações e ajudam o leitor a se identificar com o texto.

\begin{tabular}{|l|l|l|l|}
\hline Total de fontes & $\begin{array}{l}\text { Oficiais, oficiosas e } \\
\text { independentes }\end{array}$ & $\begin{array}{l}\text { Primárias } \\
\text { secundárias }\end{array}$ & $\begin{array}{l}\text { Testemunhas e } \\
\text { experts }\end{array}$ \\
\hline 2 & - & 2 - Primárias & - \\
\hline
\end{tabular}

Tabela 9: Fontes encontradas na edição de 31 de agosto de 2019 e $1^{\circ}$ de setembro de 2019 do jornal Diário Popular

\section{Uma corrente para João Vitor - Terça-feira, $1^{0}$ de outubro de 2019}

Nesta edição do Diário Popular, a capa apresentava uma foto de grande tamanho da prefeita de Pelotas, Paula Mascarenhas, com texto que foi também a manchete do jornal, anunciando que a prefeitura iria atrasar salários dos servidores municipais. Outras chamadas, como a proposta de implementação de novo parque na cidade, novas viaturas para a o Batalhão de Polícia de Choque, a liberação das verbas de custeio das instituições federais de ensino, além de chamadas para colunas, estão na capa. O tema da página 3 possui uma breve chamada, com o texto "Criança precisa de ajuda para fazer cirurgia", seguido de duas linhas explicativas.

O texto ${ }^{20}$, com assinatura de Daniel Batista, sob supervisão de Débora Borba, é apresentado em quatro parágrafos e três quadros explicativos. Possui duas fotos. Em maior destaque, a imagem de um bebê em uma poltrona. Em menor, o bebê no colo de 


\section{Anteiver}

uma mulher. O tema desta matéria mostra a campanha para ajudar a criança de sete meses, que precisava de uma cirurgia para correção de doença no crânio.

O primeiro parágrafo do texto é aberto explicando a craniossinostose, doença que afeta o menino João Vitor. O texto continua, citando que o procedimento é oferecido pelo Sistema Único de Saúde e custa R \$ 56 mil na rede particular, mas sem citar a fonte dessa informação.

No segundo parágrafo, a mãe de João Vitor, Núbia Oliveira, explica o surgimento da suspeita da doença e a saga da família até um diagnóstico. No terceiro parágrafo, é falado sobre os passos tomados pela família em busca de tratamento. Neste, um documento é citado como fonte para a marcação de uma consulta. Depois, conta como foi a consulta e cita um médico, hospital e Secretaria Municipal de Saúde, mas todos a partir da fala da mãe.

O quarto parágrafo traz um relato da avó do menino, Eduvirges Oliveira, falando sobre a rotina da criança, ao lado do marido dela, Arturino da Rosa, que é citado apenas a partir da fala da esposa. A mãe, Núbia Oliveira, volta a aparecer neste parágrafo, falando sobre a luta por tratamento médico, citando várias pessoas, mas sendo ela a fonte para tais informações. No último, parágrafo, a mãe fala sobre a espera por uma ajuda do Ministério Público, mas sem citar nada proveniente do órgão.

Nos quadros explicativos, o primeiro traz uma nota da Secretaria Municipal de Saúde, falando que buscava encaminhamento para o paciente. Na sequência, o mesmo quadro traz um posicionamento da Assessoria de Comunicação da prefeitura, dizendo que o agendamento da cirurgia seria feito rapidamente e que uma consulta estaria marcada para o dia 11 daquele mês.

O segundo quadro explicativo traz informações da Sociedade de Pediatria de São Paulo sobre a doença e tratamentos. O último quadro fala sobre maneiras de ajudar a família, mas sem citar qualquer fonte. 


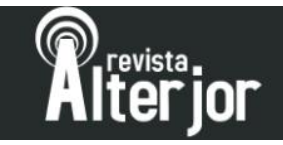

Percebe-se que o texto utiliza-se de seis fontes de informação. A mãe, Núbia Oliveira, é fonte primária a partir da definição de Lage (2009), ao aparecer no texto falando sobre fatos, versões e números quanto à espera por atendimento e a saga do filho. A avó, Eduvirges Oliveira, é considerada, a partir de Lage (2009), uma fonte secundária, ao ser citada construindo o contexto ambiental do dia a dia da criança. $\mathrm{O}$ documento pode ser utilizado como uma fonte primária pelas definições de Lage (2009), pois também oferece uma versão.

As Secretaria de Saúde e a Assessoria de Comunicação são os casos típicos de fontes oficiais na premissa de Lage (2009), ao apresentarem versões de órgãos governamentais. Por fim, a Sociedade de Pediatria de São Paulo é o caso de fonte expert na definição de Lage (2009), pois traz a versão e a interpretação de o que é a doença e quais os procedimentos para tratá-la.

Percebe-se ao analisar este texto que ele versa bastante sobre o número de fontes, lhes fazendo dialogar entre si e complementando-se. Não percebe-se a ausência significativa de alguma fonte, já que há versões de todos os núcleos, e testemunhas, oficiosos ou independentes, não parecem se encaixar no contexto do material produzido.

\begin{tabular}{|l|l|l|l|}
\hline Total de fontes & $\begin{array}{l}\text { Oficiais, oficiosas e } \\
\text { independentes }\end{array}$ & $\begin{array}{l}\text { Primárias } \\
\text { secundárias }\end{array}$ & $\begin{array}{l}\text { Testemunhas e } \\
\text { experts }\end{array}$ \\
\hline 6 & 2 - Oficiais & $\begin{array}{l}2 \text { - Primárias } \\
1-\text { Secundária }\end{array}$ & 1 - Expert \\
\hline
\end{tabular}

Tabela 10: Fontes encontradas na edição de $1^{\circ}$ de outubro de 2019 do jornal Diário Popular

\section{Considerações finais}

Abordar um tema complexo como o posicionamento de um jornal é sempre complicado. Ainda mais tratando-se de uma instituição centenária, como o Diário Popular, que passou por tantas fases ao longo de sua história. É imprescindível destacar que, numa rotina jornalística, o grande inimigo da qualidade pode ser o 


\section{Ritieior}

tempo. Em poucas horas, o repórter precisa manejar diversos passos, e entre eles inclui conversar com a fonte, que também possui sua própria rotina e pode acabar não contribuindo naquele momento. Tantas discussões surgem diariamente sobre a qualidade da informação, mas no dinamismo do mundo que vivemos, o contato com as fontes torna-se complexo e rotinizar acaba sendo uma saída quase natural.

As fontes são essenciais na construção do texto jornalístico. Servem para interpretar, fornecer versões ou ambientar histórias, conforme explica Lage (2009). Suas diversas categorias, conforme foi explanado ao longo deste trabalho, em conjunto, ajudam a criar a harmonia para o texto e um equilíbrio de ângulos. Elas são importantes para criar um texto plural e basear-se em apenas um relato pode gerar o problema de fugir de uma perspectiva real, seja por esta pessoa ter convicções íntimas que afetem sua opinião, seja por ser um observador do fato a partir de uma ótica particular.

Esta pesquisa, portanto, buscou analisar as fontes que os repórteres do Diário Popular usam em matérias destinadas à sua página de temas especiais. O objetivo foi trazer uma reflexão sobre a aplicação das fontes no jornalismo impresso do Diário Popular e compreender como as fontes se apresentam. Durante as análises, as fontes foram categorizadas, com base nas definições de Lage (2009) e nas técnicas de Análise de Conteúdo a partir de Bardin (1977).

Em um jornal tão presente na vida do público pelotense, percebeu-se que grande parte dos textos observados conta com a presença de pessoas trazendo vivências que ambientam as histórias, agindo como um pano de fundo para a informação que será trazida. Foi identificado também que, apesar de contar as histórias a partir de personagens base, sejam eles fontes primárias ou secundárias pela definição de Lage (2009), o Diário Popular trouxe muitos posicionamentos de fontes oficiais, que Lage (2009) define como ligadas a instituições públicas.

Na primeira edição, abordando o período de matrículas, pode-se perceber que apenas duas fontes foram utilizadas, ambas com posicionamentos oficiais, o que 


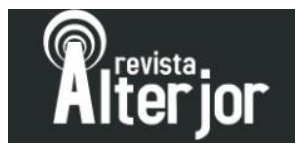

causa este desequilíbrio citado, já que em momento algum traz qualquer outra versão que não a dos órgãos públicos. Na segunda análise, sobre a safra de camarão, as quatro fontes foram utilizadas de forma complementar, sendo de três categorias distintas, sendo uma oficial, uma independente e uma oficiosa. Mas em nenhum momento o leitor foi familiarizado com as questões envolvendo a pesca, sendo apenas um grande relato. Na sequência, a terceira edição conta a história de uma personagem centenária e suas ações sociais. Com três fontes, duas contextualizando e uma fornecendo dados, é outro texto que apresenta-se como um grande diálogo entre as fontes, trazendo versões que se complementam sobre um pano de fundo.

A quarta edição analisada trouxe a história do Grande Hotel e o drama do aguardo por verbas para a conclusão de suas obras. Com quatro fontes, sendo uma responsável por realizar dois papéis em momentos distintos do texto, cria certo desequilíbrio, ao não trazer qualquer testemunha ou expert analisando o problema da demora na reforma. Com a quinta análise, sobre a mudança na cobrança das tarifas de ônibus, percebemos um uso de cinco fontes, sendo três oficiais, complementando-se. Fontes secundárias surgiram no final do texto, apenas para refletir e expor quem era o usuário, brevemente. Este texto é outro com certo desequilíbrio, já que em maior parte, é apenas um grande compilado de fontes do mesmo tipo, levando a uma falta de pluralidade, com as fontes falando em um mesmo sentido, sem gerar novos horizontes sobre o tema.

O sexto texto analisado, referente ao mês de julho, sobre a retomada do serviço de radioterapia no Hospital-Escola, dispôs de certa pluralidade, ao trazer quatro fontes, das três categorias diferentes. Mas, ainda assim, seguiu priorizando fontes oficiais, ligadas a órgãos governamentais, e sem citar os pacientes ou alunos que seriam beneficiados com o espaço. Na sétima análise, quanto à repaginação da praça Piratinino de Almeida, foram tabeladas três fontes, uma de cada categoria, dialogando entre si. Enquanto uma delas foi mapeada duas vezes, por exercer dois papéis no texto, percebeu-se que acabaram não sendo citados moradores da região 


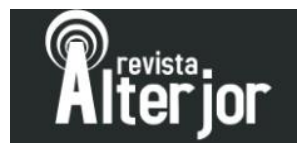

beneficiada, ou testemunhas dos crimes que ocorriam na região, significando que tal afirmação fica sem contexto ou detalhes. E, ao falar nas melhorias para a população, fica carecendo justamente desse público posicionando-se sobre o tema, em um texto majoritariamente voltado às afirmações de figuras alheias ao cotidiano do local.

O oitavo texto, sobre o mês da amamentação, é o com maior abundância de fontes. Apesar de basear-se bastante em fontes oficiais, dos diversos órgãos de saúde, oferece fontes dos outros tipos também, em um grande diálogo, onde não é possível sentir qualquer grande ausência em um primeiro momento. $\mathrm{Na}$ análise de número nove, sobre os canudos biodegradáveis criados por uma estudante, o texto baseou-se apenas em duas fontes, ambas primárias. Apesar de ser voltado a contar a história da invenção dos canudos, percebeu-se a falta de contextualização e de fontes falando sobre a proibição de canudos plásticos, fossem oficiais, fossem experts. Essa falta de contextualização implica, ao leitor que desconhece a legislação ou os problemas causados pelos canudos plásticos, numa ausência de certos sentidos quanto à importância da invenção da estudante. A décima edição, última a ser analisada, também destoou da maioria, ao contar com seis fontes, de todas as categorias, dialogando. Não houve nenhum uso excessivo de uma tipagem de fontes, ou a ausência sentida de algum personagem para tornar o texto plural e compreensível.

Isso traz uma reflexão. Percebeu-se que, sim, há uma pluralidade de fontes utilizadas no geral, o que era objetivado verificar, já que das três categorias principais, estiveram presentes fontes de todas, embora algumas tenham ficado de fora. Mas notou-se também que as fontes oficiais são esmagadora maioria, quase metade das 42 fontes presentes no texto eram dessa categoria. Interpretamos isso como algo resultado de uma rotinização, já que as fontes oficiais são de mais fácil acesso, por serem pessoas conhecidas, e são usadas, como Lage (2009) definiu, como mais confiáveis, pois suas propostas acabam sendo consideradas verdadeiras. Entende-se, portanto, que é uma saída mais confortável, já que são fontes conhecidas, de fácil acesso e cuja palavra é considerada verdadeira. O problema é que, por vezes, 


\section{Ritieior}

as fontes oficiais foram utilizadas quando experts poderiam ter dado a tônica sobre um assunto, causando certo desequilíbrio, já que confia-se demais na palavra de um único sujeito ou instituição.

Este excesso de fontes oficiais acaba tornando o texto, por vezes, similar a notas oficiais destes órgãos. Sente-se a ausência da voz da comunidade, ou do público, em alguns momentos, ficando em um tom excessivamente oficialesco e, de certa forma, burocrático. A pluralidade de vozes, ao abordar um mesmo tema, faz com que mais pessoas identifiquem-se, além de expandir as possibilidades do texto e ampliar as visões sobre o tema. Gera, assim, um debate extenso, quando possibilitado, e deixa o leitor chegar às próprias conclusões. A pluralidade de sentidos, que pode levar a diversas versões, visões ou experiências sobre o tema, também pode ofertar ao leitor a possibilidade de criar a própria opinião, além de entender múltiplos contextos sobre aquela situação. Algumas histórias, claro, são apenas relatos de vivências, como vimos em alguns textos analisados. Mas pode-se questionar, em outros casos, se não há outras versões, visões ou experiências daquelas situações, seja para interpretar o fato, seja para trazer um ângulo especialista no tema que as pessoas, por mais que convivam com aquela situação, por vezes não percebem.

Este trabalho conclui-se apresentando, para a academia e a sociedade, um recorte de como funciona o mecanismo das fontes no Diário Popular. A partir dos dados levantados, entende-se que é possível discutir melhorias, mudança de posicionamento e iniciativas que possam ampliar a gama de pessoas com espaço de fala nos jornais, seja para tornar mais interessante ao leitor, seja para variar e oferecer novas possibilidades de conteúdos.

O momento atual, com o jornalismo sendo questionado diversas vezes, e com as notícias falsas encontrando seu caminho até o leitor, é de extrema importância refletir sobre maneiras que possam ser aplicadas para melhorar a experiência do consumo de informação pela sociedade. Deve partir principalmente da academia e 


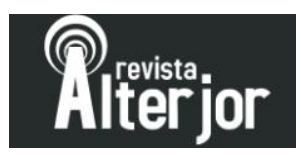

das empresas jornalísticas, de maneira que a informação plural e de qualidade permaneça e o jornalismo praticado com seriedade siga sendo interessante ao leitor.

\section{REFERÊNCIAS}

BARDIN, Laurence. Análise de Conteúdo. Lisboa: Edições 70, 1977. 231 p.

COTTA, Pery. Jornalismo: teoria e prática. Rio de Janeiro: Rubio, 2005. 174 p.

ERBOLATO, Mário L.. Técnicas de Codificação em Jornalismo: Redação, captação e edição no jornal diário. 5. ed. São Paulo: Ática, 2004. 256 p.

FACCIN, Milton Julio. Zero Hora, a voz que une os gaúchos. In: ENCONTRO NACIONAL DE HISTÓRIA DA MÍDIA, 7., 2009, Fortaleza. Anais. 2009. Porto Alegre, 2009. p. 1 - 16. Disponível em:

$<$ http://www.ufrgs.br/alcar/encontros-nacionais-1/encontros-nacionais/7o-encontro-2 0091/Zero\%20Hora-\%20a\%20voz\%20que\%20une $\% 20$ os\%20gauchos.pdf $>$. Acesso em: 9 nov. 2019.

FELIPPI, Angela Cristina Trevisan. Reflexões a respeito da identidade cultural gaúcha em Zero Hora. In: Congresso Anual em Ciência da Comunicação, 26, 2003, Belo Horizonte. Anais. 2003. Belo Horizonte: Intercom, 2003. p. 1 - 15. Disponível em: <http://www.portcom.intercom.org.br/pdfs/8990933874046702229466078710917244 2168.pdf>. Acesso em: 10 nov. 2019.

FONSECA JÚNIOR, Wilson Corrêa. Análise do conteúdo. In: DUARTE, Jorge; BARROS, Antonio (orgs.). Métodos e técnicas de Pesquisa em Comunicação. São Paulo: Atlas, 2005. p. 280-305.

GONÇALVES, Teodoro. Diário Popular: História \& fatos. 1. ed. Pelotas: Bradamante Livros, 2019. 98p.

INSTITUTO PESQUISAS DE OPINIÃO (Pelotas) (Org.). Hábitos e preferências dos pelotenses por jornal escrito: Relatório de pesquisa. Pelotas: Instituto Pesquisas de Opinião, 2019. 23 p. (Não publicado)

LAGE, Nilson. A Reportagem: teoria e técnica de entrevista e pesquisa jornalística. 8. ed. Rio de Janeiro: Record, 2009. 189 p.

NOBLAT, Ricardo. A arte de fazer um jornal diário. 7. ed. São Paulo: Contexto, 2008. 174 p.

RIOS, Dermival Ribeiro. Minidicionário escolar da língua portuguesa. São Paulo: DCL, 2005. 560 p. 


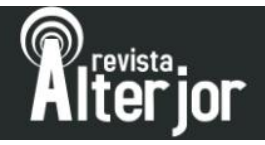

SCHMITZ, Aldo Antonio. Fontes de notícias: ações e estratégias das fontes no jornalismo. Florianópolis, Combook, 2011. 85 p.

SODRÉ, Nelson Werneck. História da imprensa no Brasil. 4. ed. Rio de Janeiro: Mauad, 1999. 501 p.

SPANNENBERG, A. C. M.; BELAFONTE BARROS, C. V. Do impresso ao digital: a história do Jornal do Brasil. Revista Observatório, v. 2, n. 2, p. 230-250, 30 maio 2016.

TRAQUINA, Nelson. Teorias do jornalismo, porque as notícias são como são. Florianópolis: Insular, 2004. 